\title{
A TALE OF ASIA'S WORLD PORTS: The Spatial Evolution in Global Hub Port Cities
}

Published in: Geoforum 39(1), 372-385

\author{
Dr Sung-Woo Lee \\ Centre for Shipping, Logistics and Port Research \\ Korea Maritime Institute \\ Bangbae-dong \\ Seoul, Korea \\ Tel: (822) 21052830 \\ Fax: (822) 21052839 \\ E-mail:waterfront@kmi.re.kr \\ Dr Dong-Wook Song* \\ Centre of Urban Planning and Environmental Management \\ The University of Hong Kong \\ Pokfulam Road \\ Hong Kong \\ Tel: (852) 22415554 \\ Fax: (852) 25590468 \\ E-mail: dsong@hkucc.hku.hk \\ Dr César Ducruet \\ Erasmus University \\ School of Economics, Faculty of Applied Economics \\ Burg. Oudlaan 50, Woudestein H12-13, P.O. box 1738 \\ 3000DR Rotterdam, The Netherlands \\ Tel: (31) 104081678 \\ Fax: (31) 104089141 \\ E-mail: ducruet@few.eur.nl
}

* Corresponding Author 


\title{
A TALE OF ASIA'S WORLD PORTS: The Spatial Evolution in Global Hub Port Cities
}

\begin{abstract}
Globalization and transport revolution, logistics integration, and the consequent expansion of port area and hinterland in the maritime industry have redefined the functional role of ports in supply chains and have generated a new pattern of freight distribution. This phenomenon again requires a new approach towards port development and related urban planning. Such changes have inevitably influenced the spatial structure of hub port cities. As existing models on spatial and functional evolution of ports and cities are mainly derived from European and American cases, this paper attempts to introduce evidence from an Asian perspective, focusing on the particular case of global hub port cities such as Hong Kong and Singapore.
\end{abstract}

Keywords: Spatial Evolution, Hub Port City, Asian Consolidation Model. 


\section{INTRODUCTION}

Globalization and transport revolution (especially, containerization and its substantive influence on global commerce and trade) become a central issue for almost all segments of industries in a global scale (e.g., Friedman, 2005). Consequently, the growing need for logistics integration and the expansion of port areas, such as the foreland and hinterland, have redefined and reshaped the functional role of ports in global supply chains. Thus, this phenomenon generates a new pattern of freight distribution and a new approach towards port development and related urban planning. For example, Notteboom and Rodrigue (2005) point out that a number of load center ports focus on inland terminals and multimodal networks to preserve their attractiveness and to fully exploit potential economies of scale against their rival ports.

This change has significantly affected ports (in particular, container ports) in Asia, leading to the development of distriparks, logistic centers, free trade zones and other similar actions in order to obtain and/or sustain their overall attractiveness or competitiveness. In this process, the spatial and functional changes in port peripheral areas have considerably impacted port cities. A city and a port interplay with each other as a single node in terms of economic and spatial structure. Urban growth affects port development, while the latter 
affects urban functions from the economic, cultural, social, and environmental perspectives.

In accordance with the observation of Notteboom and Rodrigue (2005), Asian hub port cities such as Hong Kong and Singapore have maintained their respective eminent positions without significant hinterland coverage or inland terminal supporting systems. The rise of hub port cities clearly illustrates the transport revolution. In this context, Hambleton, Savitch and Stewart (2002) argue that globalization encompasses an enormous range of activities supported by rapid changes in transportation and communication that has made transmissions across national boundaries much less expensive. Countries and cities that are far apart can be closely connected. Port cities have enjoyed such an advantage for a long time, given their ability to connect remote forelands through maritime transport, as Adam Smith (1776) points out in the case of London and Calcutta.

However, few port cities have become truly global hub port cities. After the early stages of port growth, inducing urban and industrial growth, the symbiosis often declines as ports and cities follow their own developmental logic through spatial and functional separation. Researchers have not yet identified the factors that allow for a continuing symbiosis into global hub port cities, notably from an Asian perspective. 
Having the aforementioned in mind, this paper provides a conceptual model of port-city relationships in the case of Asian hub port cities, which are analyzed in light of modern trends among European and American load centers. First, it introduces how the existing literature has explained port developments in two different contexts (i.e., developed and developing countries) and how such developments have influenced port-city relationships. Second, in the context of globalization, an Asian deviation from regional and universal models of port and port-city development is presented through the case of Hong Kong and Singapore.

\section{GLOBAL AND REGIONAL TRENDS IN PORT DEVELOPMENT}

\subsection{Global Trend}

Stimulated by the removal of national borders and the growing interactions among regions, globalization has robustly altered the traditional role of ports as the centre of transport activities. Transportation revolutions, such as containerization and intermodalism, have contributed to such changes. Gateways, the nodal points through which intercontinental containers are transhipped onto continental axes, could become hub port cities as a result of such influences (Fleming and Hayuth, 1994). Due to these globalization trends, countries 
and regions are competing in one (and only one) global market, which has resulted in a dramatic increase of competition in international trade (Song, 2003). As seen in Table 1, changing maritime systems have led to competition as well as co-operation in the port industry.

\section{[INSERT TABLE 1]}

Shipping lines have become increasingly monopolist players in the market as they attempt to consolidate via mergers and alliances. Whereas ports are fixed in space, ships have the ability to easily move. Due to this limitation, ports are dependent on the shipping lines. In addition, carriers and alliances have reshaped their operation networks by introducing doorto-door, round-the-world, and pendulum services, especially on the main east-west trade lanes (Notteboom and Rodrigue, 2005). In order to meet greater demands from shipping lines, ports are forced to respond by enlarging back-up areas, with the creation of logistic centers and new terminals, so as to enhance and/or sustain their relative competitiveness.

In these circumstances, a skyrocketing increase in international trade competition leads to greater traffic concentration among several hub ports. Such phenomena have taken place while ports become 'pawns in the game' of global players such as shipping lines (Slack, 
1993), seeking to concentrate their services on a few hub ports to save cost and time. This trend is clearly reflected in the rank of hub ports of container handling cargoes since 1990 as shown in Table 2. Major hub ports are located in Asia, intensively competing against one another under the borderless economy and globalization.

\section{[INSERT TABLE 2]}

\subsection{Ports and Regionalization}

Before turning to the theoretical aspects of port's spatial development, it is necessary to understand why Western-based or -centric models have been unable to fully reflect the regional essence of port-city development in Asia. In particular, because globalization and regionalization are parallel but interdependent phenomena, Western-based or -centric models of port development are unlikely to be universally relevant. Notably, because most port models are elaborated from European and American experiences, they may not be sufficient to explain recent and specific changes in other regions, especially in Asia (Arasaratnam, 1992). In particular, a vision of the world separating 'developed' from 'underdeveloped' countries is not suitable for understanding how the unique characteristics

of the Newly Industrialized Countries (NICs) - that is, Hong Kong, Singapore, Taiwan, and 
South Korea - provide an insight into Western port development and management patterns.

Figure 1 illustrates an idea of how global forces are facing regional specificities that shape port systems into major market areas. This figure has also a multi-scalar dimension; it encompasses the spatial pattern of port systems at various regional scales from the coastal range (e.g., North America East Coast) to the continental area (e.g., Western Europe). There are also local implications, because the situation of a port city in a regional system will directly impact port-city spatial and economic relationships at the local level (Ducruet, 2005a).

\section{[INSERT FIGURE 1]}

We can derive from this figure some important issues concerning the principles of port and port-city development. As revealed in Figure 1, inland transportation and its corollaries are of central concern to European and American ports, but this is not the case in Asia. America and Asia share the common issue of coastal concentration, which is not obvious in Europe given the inland centrality of the megalopolis (e.g., London-Rome). This might explain also the specific situation of European port cities; the dependence on inland markets is an advantage for the development of port functions (i.e., gateways), but it is a limitation for the diversification of urban functions in coastal cities (i.e., specialization in transport- 
related functions) (Rozenblat, 2004; Ducruet, 2005b). Compared with North America and Europe, the Asian specific trend of limited inland penetration (Ducruet and Jeong, 2005) is a common feature among island states and former colonial areas in Latin America, Africa, and Oceania. Thus, strategies in respect of transport operations must cope with long-term inheritance to efficiently serve the markets in terms of the different geographical, economic, and institutional regimes (McCalla et al., 2004).

A brief review of the literature on port development systems and port-city relationships in two different contexts (i.e., Western and developing countries) allows for further investigation into an Asian centric case, namely Hong Kong and Singapore, the two Asian hub port cities. In order to build a specific model for hub port city evolution, models of port growth in developed and developing countries will be introduced through common and recurrent issues like concentration, deconcentration, and competition.

\section{PORT DEVELOPMENT MODELS IN WESTERN COUNTRIES}

\subsection{Port Systems and Intermodal Transportation}

The processes described hereafter have been taking place over a long period of time. To strengthen our approach, we first introduce major research on Western port systems (as 
illustrated in Figure 2 and summarized in Table 3) and examine evolving issues like port competition and the relationships between foreland and hinterland, within or between port cities, and among countries and regions.

\section{[INSERT FIGURE 2]}

\subsubsection{Port as Concentration Points between Hinterland and Foreland}

Mayer (1957) emphasizes port competition through investigating rail transport costs from ports to hinterlands. A study by Weigend (1958) focuses on the relationship between foreland and port in terms of economic advantages of transport between sea, port, and land; this prefigures the port triptych (Vigarié, 1979) defined by the system linking foreland, hinterland, and the port node between them. Bird (1963) suggests an anyport model of port spatial evolution. It consists of six phases addressing the shift of port functions towards deep-sea locations, resulting from the pressure on land space at the upstream port city and from the increasing size of ships. In this context, Bird's study asks how a port system develops and interacts with its hinterland and land transport system.

From the beginning of concentration studies in the late 1960s, researchers studied the 
theories of port growth, examining geographical coverage, concepts, and methods. Rimmer (1967a and 1967b) found that the inter-port distribution of traffic became more concentrated as the transport network penetrated into the hinterland from a few main ports in New Zealand and Australia. His model explains the change from scattered ports to highpriority route, port annexes through the interaction between ports, nodes, and transport networks. Kenyon (1970) suggests that explanations of port competition have expanded to include other factors, such as labour costs and productivity, rail connection, port access, and land availability in the United States.

During the 1980s and 1990s, most studies focused on the initial phenomena of containerization and globalization, such as port hierarchy, scale economies, and intermodal systems (Hayuth, 1981; Hoyle and Pinder, 1981; Barke, 1986; Hoare, 1986; Slack, 1985 and 1990; Starr, 1994). Hayuth (1981) suggests a more radical spatial deconcentration process on the dynamics within container port systems. His model resulted from research on the U.S. container port sector and is of particular interest to studies on the European container port sector.

[INSERT TABLE 3] 
In his five-phase model, Barke (1986) introduces a process of port deconcentration, resulting from traffic congestion and space limitation within rapidly growing port areas. In spatial terms, this process is also a shift of port activities from urban centres to less congested suburban or peripheral sites.

\subsubsection{Ports as Nodes in Intermodal Systems}

Hoare (1986) argues that the concept of hinterland should be revised and adapted to the changes in advanced societies in the context of intermodalism: from area to linear organisation. Through reviewing previous studies (Hayuth, 1981; Slack, 1985), Hoare concludes that hinterland-based analysis no longer has any relevance. Slack (1990) suggests that the additional stage model is slightly different from Taaffe et al. (1963)'s six-stage model, given the fact that redundant nodes situated off the main routes will be dropped. Consequently, he emphasizes the importance of advancing intermodal systems. Other research (Fleming, 1989; Fleming \& Hayuth, 1994) suggests that dramatic changes in the pattern of freight transport and port competition have resulted from the rise of intermodal transport in North America since the early 1980s. Kuby and Reid (1992) underline that general cargo ports in the U.S. show less concentration than in Hayuth (1981)'s model of container concentration. In addition, they foresee that technological innovations are 
expected to continue the concentration trend. Starr (1994) points out that port authorities have initiated and supported the competition between Baltimore and Hampton Road for the position of mid-Atlantic load centre under the changing shipping environment. He explains the phenomenon as a result of mega-ships, minimized vessel costs, and decreased port calls.

\subsubsection{Ports as Agents of Regionalization and Globalization Processes}

While previous studies illustrated behaviour within a single country, research after 1995 mainly focused on applying results to larger regional areas. New concerns that focus on specific areas have emerged from intensive globalization trends. Charlier (1996) illustrates that the development stages suggested by Hayuth (1981) are also valid when international ports, such as Rotterdam and Antwerp, compete for load centre position. In addition, Notteboom (1997) demonstrates the unique concentration and stagnation in European port competition between 1980 and 1994, which slightly differs from that of previous works. He suggests that the future development of the E.U. container system will be influenced by technological and organizational evolutions in the triptych foreland-port-hinterland that emphasize the interaction between global and local forces. In this context, Notteboom and Rodrigue (2005) introduce a regionalization phase in port and port system development in terms of port spatial evolution, in contrast with the limitation of Bird's anyport model . 
Although this may explain the relationship between port and hinterland in respect to logistics integration, it cannot apply to the relationship between port and city.

\subsection{Port-City Relationships and Industrial Changes}

\subsubsection{Ports in Post-industrialized Cities}

Port-city relationships have changed enormously in Western countries from industrialization to post-industrialization to post-modernism (Norcliffe et al., 1996). These phenomena have been identified by researchers within the broad framework of globalization, scale economies, transport revolution, post-industrialization, urban expansion, and waterfront redevelopment. Generally, Western ports have undergone earlier and broader changes than other ports for three main reasons, which are summarized as follows:

(i) Location: Economies of scale have influenced transport revolution. The impact can be seen through mega-ships, mega-terminals (Rodrigue, Comtois and Slack, 1997), and containerization (Notteboom, 1997). These trends have altered the location factors of port activities, which increasingly require deep sea, large open space, and efficient transport, pushing these activities out of the city or making them disappear 
altogether. However, as seen in Table 2, containerization has privileged existing port cities, with few exceptions, that are located close to shipping lanes and away from urban settlements and markets (e.g., Laem Chabang, Gioia Tauro, Tanjung Pelepas). Some major container ports are closely located to both maritime corridors and global cities, such as Felixstowe (London) and Port Klang (Kuala Lumpur).

(ii) Cost: Economies of scale have influenced the location patterns of industries. Particularly, manufacturing industries need to reduce costs to maintain their competitiveness in the world market. However, Western counties have already reached high labor, rental, and transport costs. Under these circumstances, manufacturing industries have been obliged to move overseas. The volume of local cargoes has been rapidly reduced. As a result, ports have decreasing functions within their surrounding cities.

(iii) Business environment: Economies of scale have indirectly impacted the living conditions in the city environment. Governmental institutions and independent associations are increasingly concerned with environmental issues and seek to maintain a high standard of living in terms of air and water quality, landscape, heritage, and shore amenities. In this respect, waterfronts bring both traffic congestion 
from ports and unique spaces for daily relaxation and consumption. This has encouraged ports and related industrial or logistic activities to shift from the inner city to outer areas. Simultaneously, obsolete port and industrial areas provide a good opportunity for use as special spaces, along with optimal income of waterfront development (Hoyle et al., 1988).

For post-industrialized cities, the trend of manufacturers moving out and populations moving in occurs in most global port cities of the world. This corresponds to the parallel shift of industries to developing countries and the de-industrialization of developed countries. As a result, port-city economic relationships are profoundly modified in Western countries; thus, contradicting definitions arise: are these relationships a reciprocal breed (Vigarié, 1979), an independent phenomenon (Boyer and Vigarié, 1982), a concomitant but indirect mutual enhancement (Vallega, 1983), or a spontaneous interaction (Goss, 1990)?

\subsubsection{Port-City Interface as a Witness of Global Changes}

Radical technological changes in the shipping industry have forced port facilities to relocate from the urban core to more suitable locations (Hoyle, 1989). These changes have also led post-industrialized cities to redevelop their obsolete ports and industrial facilities, leading to 
a global phenomenon in waterfront redevelopment (Hoyle, 2000), for example, London's Dockland and Boston's Charlestown Navy Yard. This corresponds to new urban policies (Savitch, 1988) concerning physical planning and urban renewal in the 1970s and 1980s (Hoyle, 1989; Breen and Rigby, 1994 and 1996; Gordon, 1997a and 1997b).

Powerful local forces were obliged to overcome global forces through ports in their related cities as mentioned above. Local forces have both conflicted and harmonized with global forces as seen in the changing spatial structures of port cities. For example, the growth of New York's port activities in the nineteenth century, as well as in several other American port cities, was made possible by expanding port areas along the shoreline (Meyer, 1999, p.58). As shown in Figure 3, the growth period (1900-1950) of port areas was followed by a relative stagnation and a redevelopment of its waterfront areas into urban areas. The effects of transport revolution, post-industrialization, and globalization on New York's port industry are also reflected in its demographic growth (from 2.3 million people in 1850 to 7.5 million people in 1990) and its decline in transshipment of goods (from 115 million tons in 1979 to 41 million tons in 1995). The case of New York confirms in some way the model of port-city interface evolution proposed by Hoyle (1989), suggesting successive stages of port-city separation and redevelopment. However, this model does not include recent stages or differing evolution in specific regions. 


\section{[INSERT FIGURE 3]}

\section{PORT DEVELOPMENT MODELS IN DEVELOPING COUNTRIES}

At the starting point of port evolution in industrialized European countries, ports were the gateways to the outside world, backing the search for new export markets and natural resources. During colonization, ports played a crucial role as trading places, but also as centers of technological transfer, starting with the normalization of infrastructures to allow a direct connection to Western ports.

However, general port characteristics were different in advanced and developing countries (Hoyle, 1969). Advanced ports were usually developed from fishing or naval harbors, while colonial ports were located in already established cities, playing a pivotal role between immediate markets and external interests (Murphey ${ }^{1}$; Basu, 1985). Colonialists needed to quickly and efficiently collect natural resources from colonized countries and sell newly processed goods in their territories. Thus, they sought accessible places with deep water, large spaces, and good connections between the foreland, or the overseas region, and the

1 Murphey, R., Colonialism in Asia and the Role of Port Cities. Draft version sent by the author. 
hinterland, or the interior region (Kuby and Reid, 1992). Consequently, most colonial ports in Asia, Africa, and the Americas were built in places favorable for colonial interests. At this first stage, primary colonial cities were also ports (Jones, 1990), with a similar urban and port hierarchy along trading coasts (Broeze, 1985; Knight and Liss, 1991). Counter examples can be found, notably in India, with the continuous decline of the linear correlation between port city population and port traffic as well as the emergence of new ports outside traditional port cities (Kidwai, 1989).

In this context, many researchers have concentrated on the growth and functions of Western and colonial ports (Hoyle, 1969; Charlier, 1992). Some comparative studies have examined ports in terms of the geographical spectrum, notably in the context of globalization processes, which have occurred over a short time period. Figure 4 and Table 4 illustrates the various focus of previous researchers together with their positions and concerns.

\section{[INSERT FIGURE 4]}

Taaffe et al. (1963) suggest an increasing level of port concentration as the degree to which such networks are rooted, functionally and historically, in the port system. 


\section{[INSERT TABLE 4]}

The resulted port concentration can cause degradation or the disappearance of minor ports in the network. Although Taaffe et al.'s (1963) work is one of the earliest studies identifying the process of port concentration, it remains conceptual and dependent on a regional scale. Hilling (1977) identifies three phases of development: surf-port, lighterage and deep-water port. His model, based on spatial consolidation and rationalization, is more methodological as it measures the changing index of port concentration.

Further works focus on management issues, like the necessity for post-colonial port cities to welcome technology transfers, in accordance to their particular trading and socio-economic context (Hilling, 1983), and the need for long-term territorial planning and economic stability based on national plans, as seen in Africa (Hoyle, 1983). The technological spread of containerization observed in Indonesia (Airriess, 1989) shows an interesting continuation of exogenous development through penetration processes between ports and hinterlands, confirmed by Hoyle and Charlier (1995) about the East African port system. In such cases, containerization is another stage of export-led development to serve the interests of industrialised countries. 
Port cities in developing countries have been less affected by globalization. Although in former colonial port systems, containerization is seen as a continuous trend of exogenous development focused on ports, the Asian case shows important deviations due to the fact that containerization has been a tool for endogenous development. Most developed Asian countries not only welcomed global networks passively but developed a strategy for productivity and innovation through the appropriation of foreign technologies. It is thus interesting to investigate the Asian case to formulate a specific model of port-city interaction in a regional and local perspective focused on hub port cities.

\section{NEW GROWTH PATTERN OF PORT CITIES IN ASIA}

\subsection{An Asian Consolidation Model}

Hoyle's model shows the evolution of port-city interaction through functional and spatial interface in terms of Western port cities. Hoyle's model has five stages: primitive city-port, expanding city-port, modern industrial city-port, retreat from the waterfront, and redevelopment of the waterfront. This explains the separation between city and port due to functional and spatial conflicts between city and port, highlighting the growth pattern in Western port cities. However, this model did not foresee different evolutions in specific 
regions. This study proposes an Asian consolidation model mainly inspired by the cases of Hong Kong and Singapore. As shown in Figure 5, the two models are very dissimilar due to the continuation of port activities close to the urban core.

\section{[INSERT FIGURE 5]}

\section{- Fishing Coastal Village}

The Asian consolidation model is marked by a recent and rapid evolution. Every stage is under the leitmotiv of port-city symbiosis. Prior to the influence of external powers, Fishing Coastal Villages exploit a relatively limited area inland and at sea through the seasonal activity of local residents and markets.

\section{- Colonial Cityport}

The Colonial Cityport marks the adjustment of some of these villages to Western shipping standards, in order to allow pendulum services and exploit close hinterlands. Small harbours are turned into ports, and a hierarchical structure develops along the coastal urban system. Because of limited inland penetration (see Figure 1), the Asian port city 
continuously concentrates industries and populations around the original core, with port facilities expanding as trade increases. Few studies have analysed the inner patterns of port cities in developing countries (Gleave, 1997). In the Asian case, spatial models exist for Southeast Asia (McGee, 1967), India (Kosambi and Brush, 1988), and South Asia (Eliot, 2003). However, even if Southeast port cities are similar to colonial port cities, Northeast Asian port cities might not fit the same pattern (e.g., Japan, Korea, China).

\section{- Entrepôt Cityport}

The Entrepôt Cityport is a continuation of the external influence, defined by the improvement of port facilities, the expansion of Western quarters adjacent to the original urban core, and the rural exodus from inland areas, as port and pre-industrial activities require a considerable amount of labour. For instance, the issue of functional mixture between European colonial quarters and the new CBD formation is not relevant for Northeast port cities and, inversely, the importance of reclamation from the sea is not a dominant trend in Southeast Asia, except in the Singapore case. Such places become important relays to connect Western countries through maritime trade. 


\section{- Free-Trade Port City}

The Free-Trade Port City is characterised by a series of government policies which aim at pursuing the modernisation process according to world standards. The important and specific inheritance of the previous stages has fostered new models of economic development where ports play a major role. Port facilities quickly adapt to international standards like containerization through drastic measures. The enormous benefits of industrial development allow for heavy investment in port modernization. Port areas continue to concentrate cargos in direct relation with the local economy, reaching high levels of terminal productivity. Logistics parks (or distriparks), special economic zones, and mega-terminals (Feng and Chia, 2000) altogether form another specificity of the Asian case. In the 1960s, a wave of free zone development spreads in Asia on places such as Kaoshuing in Taiwan (1966), Masan in Korea (1971), and, of course, Hong Kong and Singapore as free ports and already developed business environment. Resulting from transport and logistics revolution, these components of new generation port cities strongly influence port city spatial structures. If on one side, port-city growth has led to land-use conflict and transportation congestion at the port-city interface in Western countries (Hoyle, 1988; Norcliffe et al., 1996), on the other hand, it has urged port and city players to find new forms of governance and planning in Asian port cities (Cheung, Tong and Slack, 2003). 


\section{- Hub Port City}

Hub port cities' development can be described in three respects in terms of the economies of scale they provide compared to other port cities:

(i) Location: Transport revolution and the economies of scale have encouraged the development of mega-ports at strategic location between routes and between markets, with accessible and available land reserves.

(ii) Cost: Multi-national corporations (MNCs), affected by economies of scale and globalization, have looked for favourable places to save costs and launch new markets (Holly, 1996). This was the case of the Asian dragons, which provided MNCs with market potential and low labour costs for manufacturing. Notably, this trend has been reinforced by China's Open Door Policy and its membership in the World Trade Organization (WTO).

(iii) Business Environment: A number of Asian countries have embraced the neo-liberal model of free trade and laissez-faire. Their "economic liberalization" policy prompts 
privatization and deregulation (Brohman, 1997). Thus, many MNCs have gathered in Asian countries where the political environment has also stimulated the advancement of port and urban areas. Such trends are fundamental to understand the advent of global hub port cities.

The city, which has become a global centre not only for industries but for tertiary and tourism activities, redevelops the colonial port through a Western-like waterfront project that favours public recreational areas. To sustain port efficiency without closing existing port installations, distriparks and container freight depots are developed in port back-up areas for cargo consolidation. However, containerization and urban development keep developing contiguously despite very high population density, as public spaces are adjacent to modern port areas. Thus, a major feature of Asian port cities is the successful management of density within a constrained and diverse environment as a result of a rapid urban and port growth.

In this respect, it would be expected that efficient port and urban planning result from excellent port and urban policies. Appropriate port policy inside the port and urban policy outside of the port have helped to overcome space limitations by maximizing port facilities and compacting land use. These polices have also reduced traffic congestion through 
restricting transportation policy and discriminating land use. Such phenomena, observed in hub port cities, seem to constitute an important deviation from traditional port-city models.

\section{- Global Hub Port City}

Global changes have caused the dramatic rise of several Asian cities in the hierarchical system of urban places (Shin and Timberlake, 2000, p.2257). The rapid industrialization of the Asia-Pacific economic region has triggered the globalization of production, sustained by substantial capital inflows. This has led to a demand from producers for an integrated global logistical system to handle increasingly containerized cargoes comprising finished and semi-finished goods moving to and from the Asia-Pacific economic region (Rimmer, 1998). Asian cities have raised their economic profile in the world. As Wang (1998) states, port cities are the interface between the developing hinterland and the developed foreland; Asian hub port cities, such as Hong Kong and Singapore, have played a crucial role in such an interface, connecting Europe and North America (i.e., the developed foreland) with China and Southeast Asia (i.e., the developing hinterland), respectively. As crucial global connections, these port cities have grown very rapidly as unique positions in the world.

One common aspect of all Asian ports is the new port formation, away from the original 
port-city core, with the latter continuing to exert efficient port functions. Like other regions of the world, the shift of port facilities towards outer areas is caused by a lack of capacity and accessibility in the context of continued trade growth. Although there is a common trend among Western port cites, a major difference is increasing port activity in original port areas close to the city centre. In Western port cities, traffic at former docks, which has usually ceased, has been the focus of important urban regeneration strategies. In Asia, former port installations are still crucial for international trade. As a consequence, port-city inner areas and new industrial and port outer areas are emerging as complex entities which are still highly interdependent.

In the case of hub port cities, such phenomenon also takes place, but in two cases the new port is located outside of the City-State borders (Shenzhen, mainland China for Hong Kong and Tanjung Pelepas, Malaysia for Singapore). Aside from these exceptions, the new ports are managed by the same port authorities and financed by the same State, with some localor regional-based administrative frictions: Jawaharlal Nehru (Bombay), Port Muhammad Bin Qasim (Karachi), Busan New Port (Busan), Yangsan (Shanghai), and Laem Chabang (Bangkok).

\subsection{The Experiences of Hong Kong and Singapore}


It is of common knowledge that Hong Kong and Singapore were two fishing coastal villages of a hundred dwellers before the intervention of external powers. Their advantageous location and nautical accessibility gave them a strategic importance for becoming colonial cityports, but the main reason differs. For Hong Kong, it is more its potential as a gateway to China which has been the motivation of British Empire to establish there, and start the trade negotiations. For Singapore, the main factor is its intermediate situation between East and South Asia, together with its insular configuration, a strong factor in establishing a secured entrepôt function, but the aim of Singapore has never been the conquest of the hinterland. Because the conquest of China has failed, the development of Hong Kong became more and more similar to Singapore, and the two port cities have evolved as Island-States with radically different institutions and functions than those of their neighbouring countries. For a long time, they remain the most advanced port cities of Asia, both in terms of port modernisation and urban radiance.

Notably, the similarity between Hong Kong and Singapore is crucial when the two cities become hub port cities. For example, Wang (1998) and Slack and Wang (2003) indicate important variation between the development stages of Hong Kong, Singapore, and Shanghai compared to the work of Hayuth (1981). This difference can be attributed to the 
unique relationship between Hong Kong and southern China created under the impact of globalization and containerization. The rise of Singapore as an ICT-based global container hub is also peculiar as it brings together the simultaneous processes of spatial agglomeration and dispersion associated with regional MNC production strategies (Airriess, 2001).

The current situation differs from the development stages based on previous studies regarding the models of port growth. Hub port cities have jumped through two or three stages of development when compared with the model of Hayuth (1981). For instance, Wang (1998), Wang and Slack (2000), and Slack and Wang (2003) have suggested a threestage model for Hong Kong based on the special trajectory for the load center and its unique relationships with its dramatically dynamic hinterland. Wang (1998) refers to its proximity to underdeveloped Chinese ports has allowed Hong Kong to achieve its load center status in a very short period of time. Slack and Wang (2003, p. 164) state "the factors that give rise to this deconcentration in East and South Asia are only partly in accordance with the model explanation. Neither internal congestion nor inadequate terminals account for the challenges presently being felt by the ports of Hong Kong and Singapore."

Rodrigue et al. (1997) suggest that the strong growth in the Asia-Pacific region creates a 
high demand for container transportation. A limited number of container ports, such as Singapore and Hong Kong, are able to rapidly grow and exploit their regional niches without much competition. However, transshipment in the two hub port cities leads to a double counting of containers, handled from one water carrier to another at the terminal. Consequently, during the 1990s, they retained their positions as the world's busiest ports as well as core global cities in Asia. In Busan, the rapid concentration of population and port growth has not produced a global city, given its dependence on Seoul's centrality in terms of decisional activities (Frémont and Ducruet, 2005). Busan and Kaoshuing (Taipei) thus suffer from the "lock-in effect" of centralized urban systems (Fujita and Mori, 1996), which accentuate their specialization in heavy industry. Thus, the hub port cities of Hong Kong and Singapore are specific individualized cases within Asia.

However, the symbiotic state of the hub port cities is facing an increasing number of limitations. Wang (1998) indicates two dimensions for Hong Kong ports regarding the space problems: first, the lack of stacking space within the port; second, the lack of stacking, parking, and repairing space outside the port. Hong Kong has taken some measures to offset these problems, such as higher port productivity and efficiency as well as high technical logistic centers and open space (OS) zones. In the case of Singapore, Zhu, Lean, and Ying (2002) argue that conductive business environments and well-developed 
infrastructures are favorable destinations for MNCs investments. Singapore's port industries are also located in dense and compact distriparks and high technical logistic centers, as a response to global and local forces such as the increasing presence of these inand outward multinational operations. This gives Singapore a highly efficient port function and a wealthy environment for urban functions.

However, Hong Kong and Singapore are not yet fitting in the functional and spatial models of Murphey (1989) and Hoyle (1989). Port and city remain strongly linked and interdependent in the two cases, through a constant renewal of this dynamic by seeking new opportunities at different levels: hinterland expansion for Hong Kong, global terminal network construction for Singapore (PSA).

Hong Kong and Singapore might have followed Hoyle's model until the early 1980s, but they confronted new changes due to post-industrialization, globalization, and China's Open Door Policy. Such factors have forced them to adapt rapidly in terms of port-city growth, port productivity and efficiency, and urban attractiveness. Under these circumstances, Hong Kong and Singapore have created a new urban growth pattern. They had undergone the stage of conflict and cooperation during the 1980s and 1990s, while such phenomena occur during the 1960s and 1970s in Hoyle's model, where it leads to a total separation between 
city and port. Waterfronts are developed in the old port cities, while the separated port grows with little chance of becoming a new city.

\subsection{Global Hub Port City Defined}

Our review of the former works allows us to formulate some specific characteristics of Asian hub port cities, mainly from the cases of Hong Kong and Singapore. First of all, both ports have managed to maintain a double leading position in both global urban and port systems, made possible by overcoming traffic congestion and space limitations through dynamic growth over a short period of time. The development of new ports in their vicinity appears to be a complement rather than a threat for the continuous prosperity of hub port cities.

\section{[INSERT FIGURE 6]}

Figure 6 helps to position the hub port city concept and its global position among other types of port cities and port-city relationships, based on the principles of intermediacy (i.e., transportation systems) and centrality (i.e., settlement systems) as defined by Fleming and Hayuth (1994). In the figure, 'cityports' are more likely to become 'general cities' in Western countries, while they continue to expand in Asia. 
The global hub port city has specific functions compared to other port cities as specified in Table 5. With the loosening of port functions, which usually occurs within important metropolitan economies, hub port cities may turn into maritime cities, where port activities constitute an important but secondary function of the local economy, and then become general cities, which are similar to non-port cities in terms of economical structure. In the meantime, new gateways (interfaces between forelands and hinterlands) and new hubs (strategic relays for the concentration of shipping lines) will absorb these activities in more suitable locations.

\section{[INSERT TABLE 5]}

\section{CONCLUDING REMARKS}

This paper has examined hub port cities in Asia by reviewing the existing literature in terms of port spatial evolution. Asian hub port cities have undergone a unique model of evolution in terms of port-city interface. This uniqueness is believed to be induced from simultaneous internal and external forces. Drastic changes in the regional environment have caused hub port cities to evolve in a specific way that is different from their international counterparts. 
To respond to such changes, new policies have been implemented, and the city and port have become more cohesive and closely connected to increase competitiveness. The phenomenon of consolidation distinguishes Asian hub port cities from the theory of separation proposed by previous contemporary researchers such as Hoyle (2000; 1996; 1989 and 1983). The unique process of port evolution in Asian hub port cities is referred to as the Asian consolidation model to give a distinctive identity to the evolution of the Asian ports. Future prospects shall insist on the existence of perhaps different Asian models of port-city evolution, by enlarging the comparison to other Asian hub port cities.

\section{ACKNOWLEGEMENTS}

The authors are grateful to the editor-in-chief Professor Andrew Leyshon and three anonymous referees for their kind and constructive comments and suggestions which made a significant contribution to the current form of the paper. Usual practices are applied. 


\section{REFERENCES}

Airriess, C. (1989), The Spatial Spread of Container Transport in a Developing Regional Economy: North Sumatra, Indonesia, Transportation Research A, 23, 453-461.

Airriess, C. (2001), Regional Production, Information-Communication Technology, and the Developmental State: the Rise of Singapore as a Global Container Hub, Geoforum, 32, $235-254$

Arasaratnam, S. (1992), Pre-colonial and Early-colonial Port Towns, in Banga, I. (ed.), Ports and their Hinterlands in India 1700-1950, New Delhi, Manohar, pp. 367-372.

Barke, M. (1986), Transport and Trade, Oliver \& Boyd.

Basu, D. (1985), The Rise and Growth of the Colonial Port Cities in Asia, Center for South and South East Asian Studies, University of California, US.

Bird, J. (1963), The Major Seaports of the United Kingdom, London, Hutchison.

Boyer, J. and Vigarié, A. (1982), Les ports et l'organisation urbaine et régionale. Bulletin de l'association des Géographes Français, 487, 159-182.

Breen, A. and Rigby, D. (1994), Waterfronts: Cities Reclaim their Edge, New York, McGraw-Hill.

Breen, A. and Rigby, D. (1996), The New Waterfront: a Worldwide Urban Success Story, New York, McGraw-Hill.

Brohman, J. (1997), Postwar Development in the Asian NICs: Does the Neoliberal Model Fit Reality?, Economic Geography, 72(2), 107-130.

Broeze, F. (1985), Port Cities: the Search for an Identity, Journal of Urban History, 11, 209-225

Charlier, J. (1992), Structural Change in the Belgian Port System, Maritime Policy and Management, 15, 315-326. 
Cheung, R., Tong, J. and Slack, B. (2003), The Transition from Freight Consolidation to Logistics: the Case of Hong Kong, Journal of Transport Geography, 11, 245-253.

Containerisation International Yearbook (various years), London, Emap Business Communications Ltd.

Ducruet, C. (2004), Port Cities: Laboratories of Globalisation, Unpublished PhD Dissertation in Geography, Le Havre University.

Ducruet, C. (2005a), Spatial Structures and Trends in Port Cities: from the Local to the Global, M@ppemonde, 77: http://mappemonde.mgm.fr/num5/articles/art05106.html

Ducruet, C. (2005b), Approche comparée du développement des villes-ports à l'échelle mondiale: problèmes théoriques et méthodologiques, Cahiers Scientifiques $d u$ Transport, 48, 59-79.

Ducruet, C. and Jeong, O. (2005), European Port-city Interface and its Asian Application, Korea Research Institute for Human Settlements, Research Report 17.

Eliot, E. (2003), Chorotype de la métropole portuaire d'Asie du Sud. Mappemonde, 69, 710.

Feng, C. and Chia, K. (2000), Logistics Opportunities in Asia and Development in Taiwan. Transport Reviews, 20(2), 257-265.

Fleming, D. and Hayuth, Y. (1994), Spatial Characteristics of Transportation Hubs: Centrality and Intermediacy, Journal of Transport Geography, 2(1), 3-18.

Frémont, A. and Ducruet, C. (2005), The Emergence of a Mega Port: from the Local to the Global: the Case of Busan, Tijdschrift voor Econ. En Soc. Geografie, 96(4), 421-432.

Friedman, T. (2005), The World is Flat: A Brief History of the Twenty-First Century, Farrar, Straus and Giroux, New York.

Fujita, M. and Mori, T. (1996), The Role of Ports in the Making of Major Cities: Selfagglomeration and Hub-effect, Journal of Development Economics, 49, 93-120. 
Gleave, M. (1997), Port Activities and the Spatial Structure of Cities: the Case of Freetown, Sierra Leone, Journal of Transport Geography, 5(4), 257-275.

Gordon, D. (1997a), Managing the Changing Political Environment in Urban Waterfront Redevelopment, Urban Studies, 34(1), 61-83.

Gordon, D. (1997b), Financing Urban Waterfront Redevelopment, Journal of the American Planning Association, 63(2), 224-265.

Goss, R. (1990), Economic Policies and Seaports: Part 1 - The Economic Functions of Seaports, Maritime Policy and Management, 17(3), 207-219.

Hoare, A. (1986), British Ports and their Export Hinterland: a Rapidly Changing Geography, Geografiska Annaler, 68B(4), 29-40.

Hambleton, R., Savitch, H. and Stewart, M. (2002), Globalism and Local Democracy: Challenge and Change in Europe and North America, New York, Palgrave Macmillan. Hayuth, Y. (1981), Containerization and the Load Centre Concept, Economic Geography, 57, 160-176.

Knight, F. and Liss, P. (1991), Atlantic Port Cities: Economy, Culture and Society in the Atlantic World, 1650-1850, Knoxville, University of Tennessee Press.

Hilling, D. (1977), The Evolution of a Port System: the Case of Ghana, Geography, 62(2), 97-105.

Holly, B. (1996), Restructuring the Production System, in Daniels, P. and Lever, W. (eds.), The Global Economy in Transition, Harlow, Addison-Wesley, pp. 24-39.

Hoyle, B. (1983), Seaports and Development: The Experience of Kenya and Tanzania, New York and London, Gordon and Breach Science Publishers.

Hoyle, B. (1989), The Port-city Interface: Trends, Problems, and Examples, Geoforum, 20(4), 429-435.

Hoyle, B. (2000), Global and Local Change on the Port-city Waterfront, Geographical 
Review, 90(3), 395-417.

Hoyle, B. and Charlier, J. (1995), Inter-port Competition in Developing Countries: an East African Case Study, Journal of Transport Geography, 3(2), 87-103.

Hoyle, B. and Pinder, D. (1981), Cityport Industrialization and Regional Development: Spatial Analysis and Planning Strategies, Oxford, Pergamon Press.

Jones, E. (1990), Metropolis: the World's Great Cities, Oxford: Oxford University Press.

Kenyon, J. (1970), Elements in Inter-port Competition in the United States, Economic Geography, 46(1), 1-24.

Kidwai, A. (1989), Port Cities in a National System of Ports and Cities: a Geographical Analysis of India in the 20th Century, in Broeze, F. (ed.), Brides of the Sea: Port Cities of Asia from the 16th - 20th Centuries, Honolulu, University of Hawaii Press, pp. 207-222.

Kosambi, M. and Brush, J. (1988), Three Colonial Port Cities in India, Geographical Review, 78(1), 32-47.

Kuby, M. and Reid, N. (1992), Technological Change and the Concentration of the U.S. General Cargo Port System: 1970-1988, Economic Geography, 68, 272-289.

Lee, S.-W. (2005), Interaction Between City and Port in Asian Hub Port Cities, Unpublished PhD Dissertation in Urban Planning, University of Seoul.

Mayer, H. (1957), The Port of Chicago and the St. Lawrence Seaway, Department of Geography Research Paper, No. 49. University of Chicago, Chicago.

McCalla, R., Slack, B. and Comtois, C. (2004), Dealing with Globalization at the Regional and Local Level: the Case of Contemporary Containerization, Canadian Geographer, 48, 473-487.

McGee, T. (1967), The Southeast Asian City: a Social Geography of the Primate Cities, London: G. Bell \& Sons Ltd. 
Meyer, H. (1999), City and Port, Utrecht: International Books.

Murphey, R. (1989), On the Evolution of the Port City, in Broeze, F. (ed.), Brides of the Sea: Port Cities of Asia from the 16th - 20th Centuries, Honolulu, University of Hawaii Press, pp. 223-245.

Norcliffe, G., Bassett, K. and Hoare, T. (1996), The Emergence of Postmodernism on the Urban Waterfront, Journal of Transport Geography, 4(2), 123-134.

Notteboom, T. (1997), Concentration and Load Centre Development in the European Container Port System, Journal of Transport Geography, 5(2), 99-115.

Notteboom, T. and Rodrigue, J. (2005), Port Regionalization: Towards a New Phase in Port Development, Maritime Policy and Management, 32(3), 297-313.

Rimmer, P. (1967a), The Changing Status of New Zealand Seaports, 1853-1960, Annals Association of American Geographers, 51(1), 88-100.

Rimmer, P. (1967b), The Search for Spatial Regularities in the Development of Australian Seaports, Geografiska Annaler, 49B, 42-54.

Rimmer, P. (1998), Ocean Liner Shipping Services: Corporate Restructuring and Port Selection/Competition, Asia Pacific Viewpoint, 39(2), 193-208.

Rodrigue, J., Comtois, C. and Slack, B. (1997), Transportation and Spatial Cycles: Evidence from Maritime Systems, Journal of Transport Geography, 5(2), 87-98.

Rozenblat, C. (2004), Les Villes Portuaires en Europe, Analyse Comparative, Montpellier, CNRS.

Savitch, H. (1988), Post-Industrial Cities, Princeton, Princeton University Press.

Shin, K. and Timberlake, M. (2000), World Cities in Asia: Cliques, Centrality and Connectedness, Urban Studies, 37(12), 2257-2285.

Slack, B. (1985), Containerization, Inter-port Competition and Port Selection, Maritime Policy and Management, 12, 293-303. 
Slack, B. (1990), Intermodal Transportation in North American and the Development of Inland Load Centres, Professional Geographer, 42, 72-83.

Slack, B. (1993), Pawns in the Game: Ports in a Global Transportation System, Growth and Change, 24, 579-588.

Slack, B. and Wang, J. (2003), The Challenge of Peripheral Ports: an Asian Perspective, GeoJournal, 56, 159-166.

Smith, A. (1776) [1990], The Wealth of Nations, London: David Campbell.

Song, D.-W. (2003), Port Co-opetition in Concept and Practice, Maritime Policy and Management, 30(1), 29-44.

Starr, J. (1994), The Mid-Atlantic Load Centre: Baltimore or Hampton Roads, Maritime Policy and Management, 21(3), 219-227.

Taaffe, E., Morrill, R. and Gould, P. (1963), Transport Expansion in Underdeveloped Countries: a Comparative Analysis, Geographical Review, 53, 503-529.

Vallega, A. (1983), Nodalité et centralité face à la multimodalité: éléments pour un relais entre théorie régionale et théorie des transports, in Muscara, C. and Poli, C. (eds.), Transport Geography Facing Geography, Papers and Proceedings of the Paris Meeting, I.G.U. Working Group on Geography of Transport, June 26-29, pp. 69-88.

Vigarié, A. (1979), Ports de Commerce et Vie Littorale, Paris, Hachette Université.

Wang, J. and Slack, B. (2000), The Evolution of a Regional Container Port System: the Pearl River Delta, Journal of Transport Geography, 8, 263-275.

Wang, J. (1998), A Container Load Centre with a Developing Hinterland: a Case Study of Hong Kong, Journal of Transport Geography, 6(3), 187-201.

Weigend, G. (1958), Some Elements in the Study of Port Geography, Geographical Review, 48, 185-200.

Zhu, J., Lean, H. and Ying, S. (2002), The Third-party Logistics Services and Globalization 
of Manufacturing, International Planning Studies, 7(1), 89-104. 
Table 1. Changing Factors for and Phenomena of Port Environment

\begin{tabular}{|c|c|c|}
\hline Category & Phenomenon & Result \\
\hline $\begin{array}{l}\text { Shipping } \\
\text { Alliances }\end{array}$ & $\begin{array}{l}\text { Large shipping companies have propelled } \\
\text { mergers, take-over and alliances for } \\
\text { consolidation of these shipping liners' leading } \\
\text { role in the market in order to maximize market } \\
\text { shares and minimize running costs }\end{array}$ & $\begin{array}{l}\text { Shipping liners now duly provide } \\
\text { global networks, whereby one mega- } \\
\text { carrier or an alliance can move goods } \\
\text { freely around the global market }\end{array}$ \\
\hline $\begin{array}{l}\text { Larger Vessel } \\
\text { Size }\end{array}$ & $\begin{array}{l}\text { Larger container ships are mainly built to } \\
\text { achieve economies of scale }\end{array}$ & $\begin{array}{l}\text { Due to the depth limits of container } \\
\text { ports, fewer ports are able to directly } \\
\text { serve the giant transoceanic vessels }\end{array}$ \\
\hline Intermodality & $\begin{array}{l}\text { Inland intermodal hubs enable containers to be } \\
\text { shipped longer distances across continents to } \\
\text { establish a connection with a port }\end{array}$ & $\begin{array}{l}\text { The hinterland and foreland of the } \\
\text { port are expanded. This further } \\
\text { encourages the globalization of port } \\
\text { management and operations. }\end{array}$ \\
\hline
\end{tabular}

Source: Compiled from Song (2003, pp.30-31). 
Table 2. World Top 20 Container Ports

(Unit: 000 TEUs)

\begin{tabular}{|c|c|c|c|c|c|c|c|c|}
\hline \multirow{2}{*}{ Port } & \multicolumn{2}{|c|}{2005} & \multicolumn{2}{|c|}{2000} & \multicolumn{2}{|c|}{1995} & \multicolumn{2}{|c|}{1990} \\
\hline & Rank & TEUs $^{1}$ & Rank & TEUs & Rank & TEUs & Rank & TEUs \\
\hline Singapore & 1 & 23,192 & 2 & 17,090 & 2 & 10,800 & 1 & 5,224 \\
\hline Hong Kong & 2 & 22,427 & 1 & 18,100 & 1 & 12,550 & 2 & 5,101 \\
\hline Shanghai & 3 & 18,804 & 6 & 5,613 & 19 & 1,527 & - & - \\
\hline Shenzhen & 4 & 16,197 & 11 & 3,959 & - & - & - & - \\
\hline Busan & 5 & 11,843 & 3 & 7,540 & 5 & 4,503 & 6 & 2,348 \\
\hline Kaoshuing & 6 & 9,471 & 4 & 7,426 & 3 & 5,232 & 4 & 3,495 \\
\hline Rotterdam & 7 & 9,288 & 5 & 6,274 & 4 & 4,787 & 3 & 3,666 \\
\hline Hamburg & 8 & 8,087 & 9 & 4,248 & 6 & 2,890 & 8 & 1,969 \\
\hline Dubai & 9 & 7,619 & 13 & 3,059 & 14 & 2,083 & - & - \\
\hline Los Angeles & 10 & 7,484 & 7 & 4,879 & 9 & 2,555 & 7 & 2,116 \\
\hline Long Beach & 11 & 6,709 & 8 & 4,601 & 7 & 2,834 & 12 & 1,598 \\
\hline Antwerp & 12 & 6,482 & 10 & 4,082 & 10 & 2,329 & 14 & 1,549 \\
\hline Qingdao & 13 & 6,307 & 19 & 2,120 & - & - & - & - \\
\hline Port Klang ${ }^{2}$ & 14 & 5,543 & 12 & 3,207 & - & - & - & - \\
\hline New York/New Jersey & 17 & 4,792 & 14 & 3,006 & 11 & 2,306 & 9 & 1,898 \\
\hline Laem Chabang & 20 & 3,765 & - & - & - & - & - & - \\
\hline Bremen/Bremerhaven & 21 & 3,735 & 15 & 2,712 & 20 & 1,526 & 17 & 1,163 \\
\hline Tokyo $^{3}$ & 22 & 3,593 & 18 & 2,889 & 12 & 2,177 & 13 & 1,555 \\
\hline Gioia Tauro & 26 & 3,160 & 20 & 2,653 & - & - & - & - \\
\hline Felixstowe & 29 & 2,700 & 16 & 2,793 & 15 & 1,898 & 15 & 1,417 \\
\hline
\end{tabular}

Notes: 1. TEU refers to as a twenty foot equivalent unit, a standard measurement of 20 foot containers.

2. Tanjung Pelepas was ranked No. 19 in 2005

3. Kobe and Yokohama were of the top 10 ports before 1995, but their rank has diminished since then

Sources: Compiled from Containerisation International Yearbooks. 
Table 3. A General Model of Port Development in Western Countries

\begin{tabular}{|l|l||}
\hline \multicolumn{1}{|c|}{ Phases } & \multicolumn{1}{c|}{ Principles } \\
\hline $\begin{array}{l}\text { Preconditions for } \\
\text { containerization }\end{array}$ & $\begin{array}{l}\text { A general equilibrium exists, as the port hinterland remains unchanged and containers } \\
\text { are handled with other cargoes in the traditional port system }\end{array}$ \\
\hline $\begin{array}{l}\text { Initial container } \\
\text { port development }\end{array}$ & $\begin{array}{l}\text { The changes are concerned notably with local and traditional markets. The potential of } \\
\text { containerization as a means of enlarging tributary areas is not yet fully recognized }\end{array}$ \\
\hline $\begin{array}{l}\text { Diffusion, } \\
\text { consolidation, } \\
\text { port concentration }\end{array}$ & $\begin{array}{l}\text { The large ports reach into further vast areas and have stronger lateral extensions, as } \\
\text { lines of penetration beyond the traditional hinterland boundaries begin to emerge, }\end{array}$ \\
\hline through transport networks \\
The load center & $\begin{array}{l}\text { The ocean carrier enters the inland transport market, and the inland distribution strategy } \\
\text { tends to be considered as part of the entire voyage, a single door-to-door service. } \\
\text { Traditional hinterland patterns transformed traffic concentrates on favoured inland } \\
\text { routes, as intermodal transportation system emerge }\end{array}$ \\
\hline $\begin{array}{l}\text { The challenge of } \\
\text { the periphery }\end{array}$ & $\begin{array}{l}\text { The changing patterns of points and lines for commodity packaging and consolidating } \\
\text { become more practically significant than the traditionally defined hinterlands }\end{array}$ \\
\hline
\end{tabular}

Source: Hayuth (1981, pp.161-165).

\section{Table 4. A General Model of Port Development in Developing Countries}

\begin{tabular}{||l|l||}
\hline \multicolumn{1}{|c||}{ Phases } & \multicolumn{1}{c|}{ Principles } \\
\hline Scattered ports & $\begin{array}{l}\text { Initial scattered pattern resulting from the competition among seaports and between } \\
\text { seaports and inland centers }\end{array}$ \\
\hline $\begin{array}{l}\text { Penetration lines } \\
\text { and port } \\
\text { concentration }\end{array}$ & $\begin{array}{l}\text { Gateway ports are growing and concentrating in line with main corridors } \\
\text { Interconnection }\end{array}$ \\
\hline $\begin{array}{l}\text { Some big port cities have further agglomerated economies, growing as a result of } \\
\text { intensified competition between cities }\end{array}$ \\
$\begin{array}{l}\text { High-priority } \\
\text { linkages }\end{array}$ & $\begin{array}{l}\text { Development of trunk lines and high-priority linkages between the largest centers, } \\
\text { which reinforce further main corridors and linkages, with poorly connected ports } \\
\text { becoming more and more isolated }\end{array}$ \\
\hline \hline
\end{tabular}

Source: Taaffe et al. (1963, p. 504). 
Table 5. Specific Characteristics of Global Hub Port Cities

\begin{tabular}{|c|c|c|c|}
\hline & Port function & Urban function & Port-city evolution \\
\hline Global & $\begin{array}{l}\text { Serving major sea routes } \\
\text { Shipping line concentration }\end{array}$ & $\begin{array}{l}\text { Financial attractiveness } \\
\text { Air transport hub }\end{array}$ & $\begin{array}{l}\text { Rapid diversification } \\
\text { Maintain logistic quality }\end{array}$ \\
\hline Regional & $\begin{array}{l}\text { Hub/feeder function } \\
\text { New port outside boundaries } \\
\text { Absence of hinterland }\end{array}$ & $\begin{array}{l}\text { City-State } \\
\text { Isolation from mainland network } \\
\text { Cut from regional urban network }\end{array}$ & $\begin{array}{l}\text { Hinterland enlargement } \\
\text { Port co-opetition }\end{array}$ \\
\hline Local & $\begin{array}{l}\text { High terminal productivity } \\
\text { Cost and congestion threats }\end{array}$ & $\begin{array}{l}\text { Proximity of port and CBD } \\
\text { Lack of space }\end{array}$ & Efficient planning policy \\
\hline
\end{tabular}

Source: Compiled from various sources 
Figure 1. Regional Patterns of Hinterland Concentrations

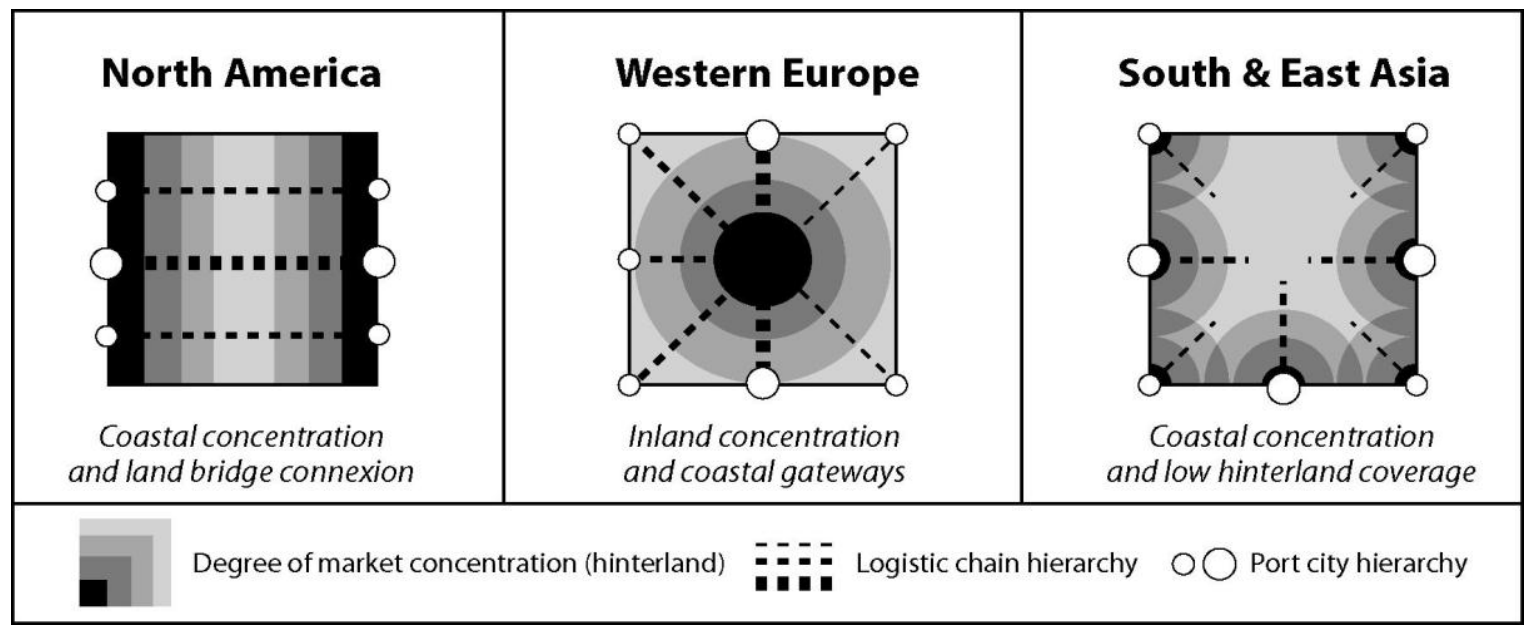

Source: Drawn by the authors.

Figure 2. Evolution of Port Issues in Western Countries

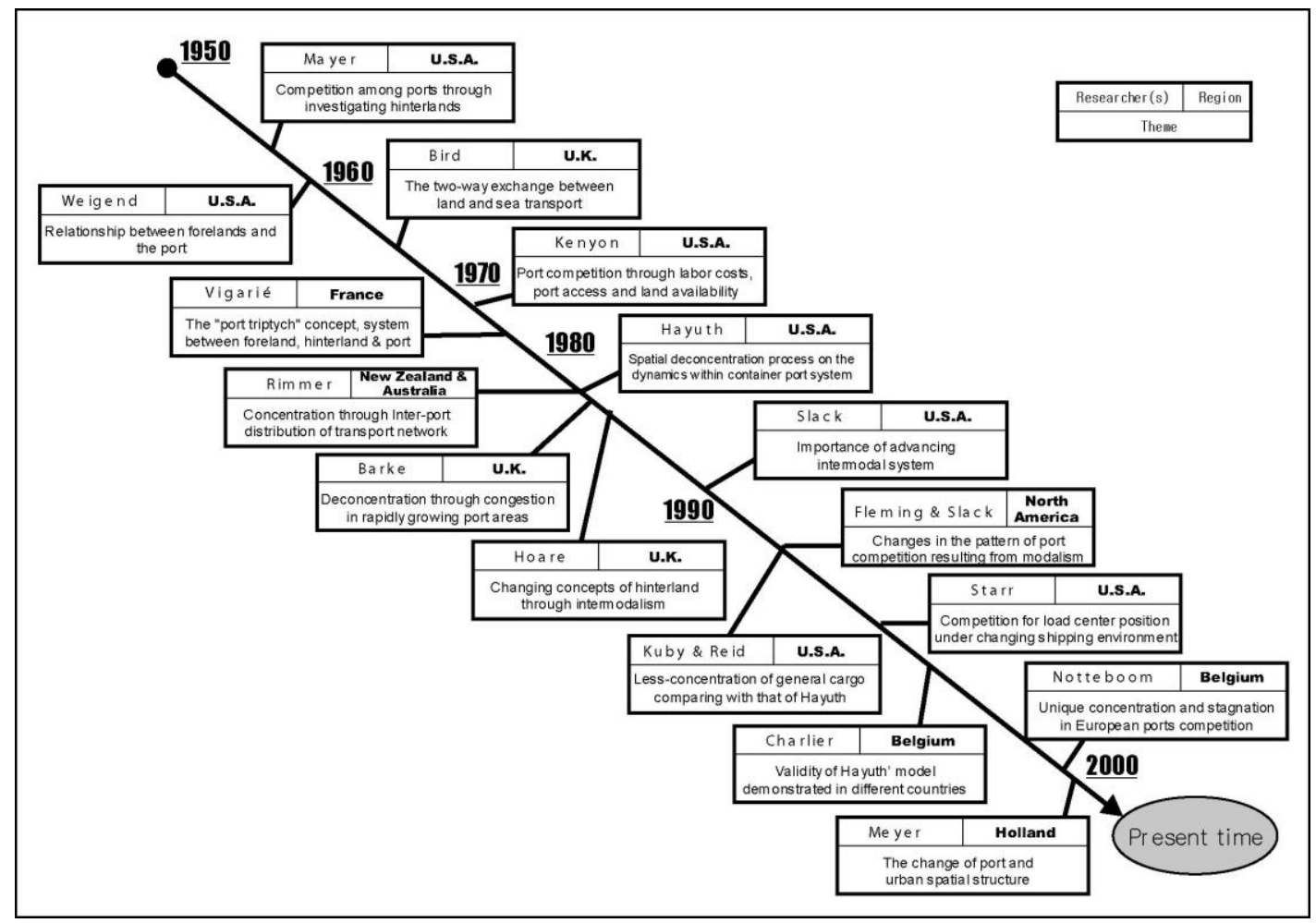

Source: Compiled from various sources. 
Figure 3. Interface between City and Port in New York (1850-2000)

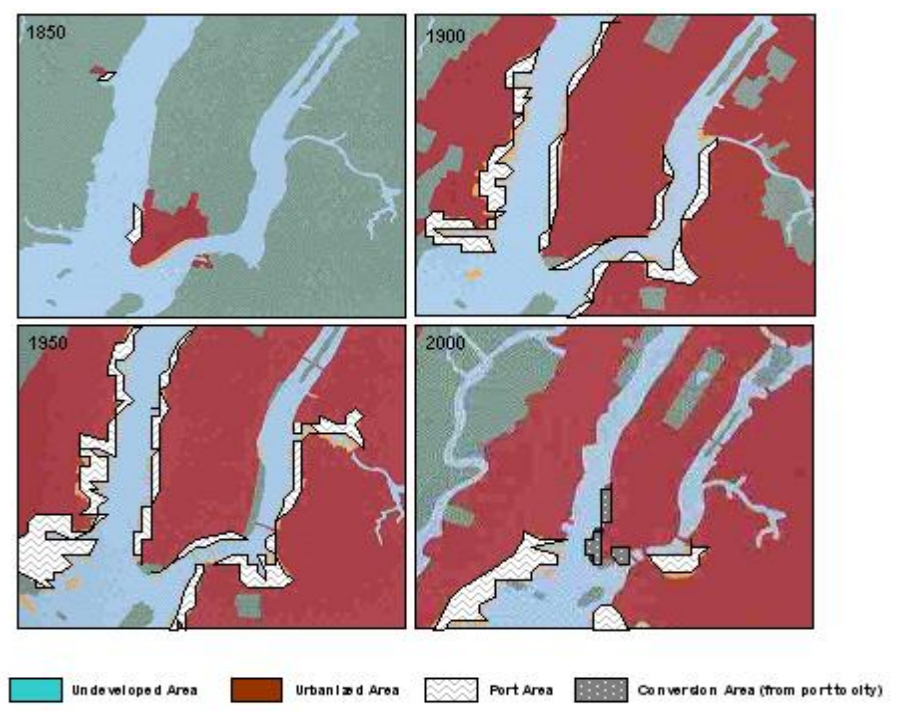

Source: Modified from Meyer (1999, pp.58-59).

Figure 4. Evolution of Port Issues in Developing Countries

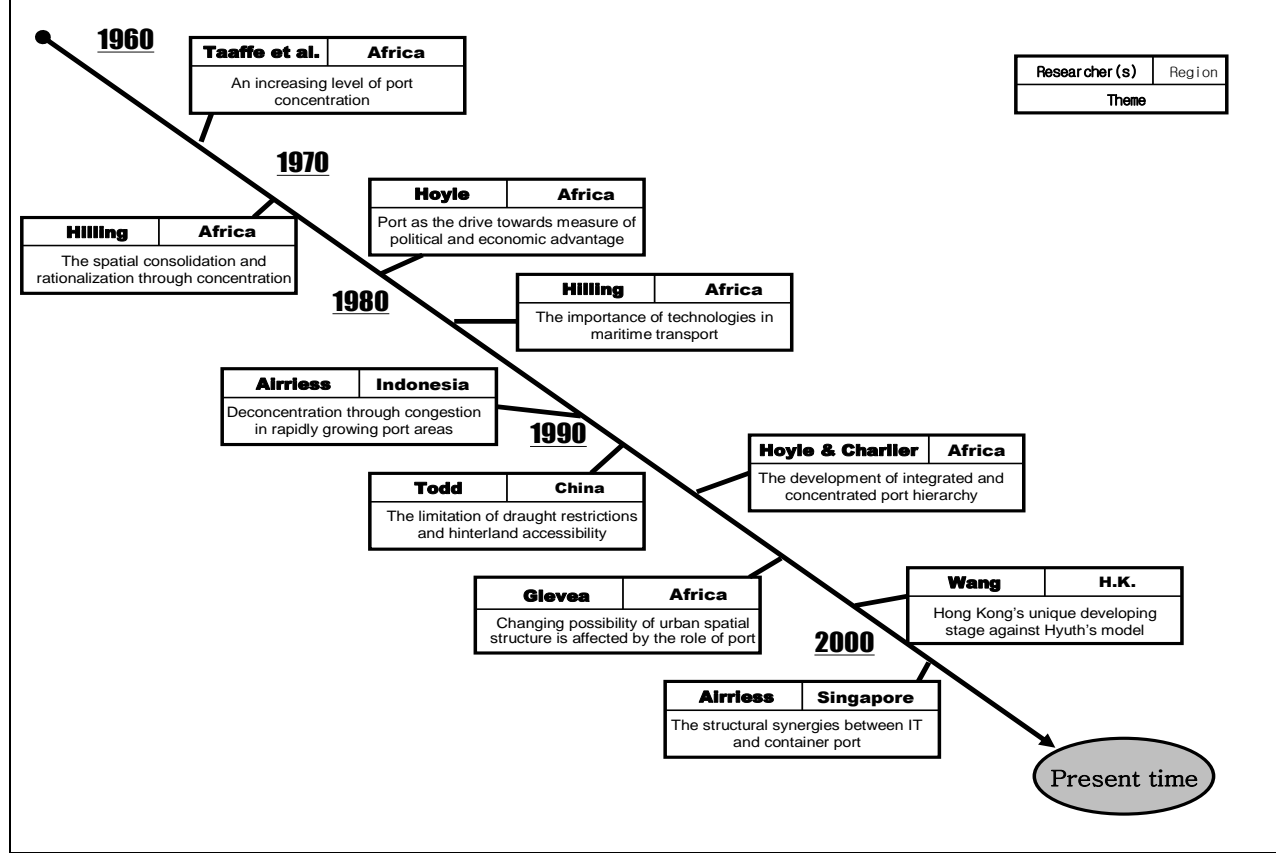

Source: Compiled from various sources. 
Figure 5. Stages in the Evolution of Western and Asian Port-City Interfaces

\begin{tabular}{|c|c|c|}
\hline WESTERN PORT CITY MOL & Period & ASIAN HUB PORT CITY CONSOLIDATION MODEL \\
\hline $\begin{array}{l}\text { Primitive cityport } \\
\text { Close spatial and functional } \\
\text { association between city and port } \\
\text { Expanding cityport } \\
\text { Rapid commercial and industrial growth forces } \\
\text { port to develop beyond city confineswith linear } \\
\text { quays and break-bulk industries } \\
\text { Modern Industrial cityport } \\
\text { Industrial growth (esp. oil refining) and } \\
\text { introduction of Ro-Ro and container facilities } \\
\text { requires separation and increased space } \\
\text { Retreat from the waterfront } \\
\text { Changes in maritime technology induce } \\
\text { growth of separated maritime industrial } \\
\text { development areas } \\
\text { Redevelopment of the waterfront } \\
\text { Large-scale modern port consumes large } \\
\text { areas of land and water space, urban } \\
\text { renewal of original core } \\
\text { General port city } \\
\text { Rising environmental concern for intermodal } \\
\text { transport, city economy develops alike } \\
\text { non-port cities }\end{array}$ & $\begin{array}{l}\text { Ancient-medieval } \\
\text { to } 19 \text { th century } \\
\text { 19th to early 20th century } \\
\text { Mid-20th century } \\
1960 \mathrm{~s}-1980 \mathrm{~s}\end{array}$ & $\begin{array}{l}\text { Fishing coastal village } \\
\text { Small community of natives practice } \\
\text { self-sufficient local trade } \\
\text { Colonial cityport } \\
\text { Dominant external interests develop } \\
\text { both port and city for raw products } \\
\text { exportation and geopolitical control } \\
\text { Entrepot cityport } \\
\text { Trade expansion and entrepot function, } \\
\text { modern port development from sea } \\
\text { reclamation } \\
\text { Free trade port city } \\
\text { Export-led policy attracts industries } \\
\text { using port facilities through tax-free } \\
\text { procedures and low labor cost } \\
\text { Hub port city } \\
\text { Increasing port productivity due to hub } \\
\text { functions and territorial pressure } \\
\text { close to the urban core } \\
\text { Global hub port city } \\
\text { Maintained port activity and new port } \\
\text { building due to rising costs in the hub, } \\
\text { possible hinterland expansion }\end{array}$ \\
\hline
\end{tabular}

Sources: Modified from Hoyle et al. (1989, p.7) and Lee (2005, p. 145). 
Figure 6. Hub Port City within the Matrix of Port-City Relationships

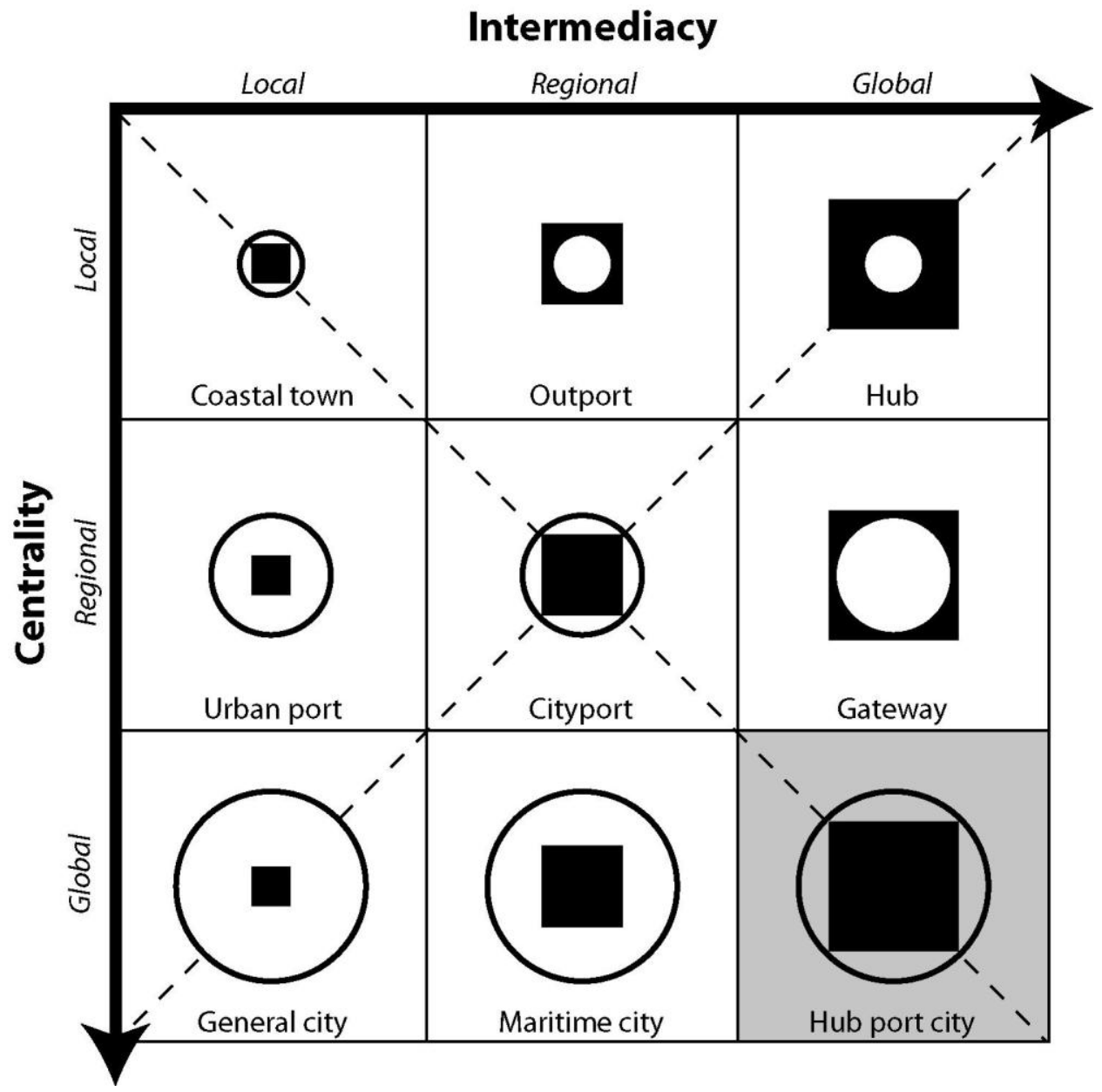

Source: Modified from Ducruet (2004, p. 22). 